\title{
ALTERNATIVE TAX YEARS AND THE REQUIREMENT OF CROSS-APPEAL: A PROCEDURAL PATH TO GIFT TAX EVASION*
}

The Commissioner of Internal Revenue often faces the problem of deciding in which year to tax a gift. ${ }^{1}$ The federal gift tax takes the form of a yearly assessment on the aggregate value of the gifts made by the taxpayer during the year. ${ }^{2}$ Hence the Commissioner must include the tax on a gift in the assessment for a particular year. ${ }^{3}$ Selecting the correct year may be difficult. For instance, the gift may be conditioned upon the occurrence of a specified event. If the gift can be valued while contingent, the transfer is taxed when made. Where such valuation is impractical, no tax is imposed until the condition is fulfilled. ${ }^{4}$ Similarly, the donor may retain powers of control. If these powers are insubstantial, the gift is taxed in the year of transfer. Otherwise, the gift is taxed only later, when control is surrendered." Should a court hold that the Commissioner chose the wrong year, the taxpayer may escape

*Rosenthal v. Commissioner, 205 F.2d 505 (2d Cir. 1953).

1. The Commissioner faces the same problem in determining income tax liability. That tax is computed upon net income received in an annual accounting period. Ini. REv. CODE $\S 42(\mathrm{a})$. And deductions must also be taken in a specified tax year. Id. $\S 43$. For general discussion of the problems involved, see 2 MIERTEns, Law of Frenzul I:*COXIE TAXATION $\$ \$ 12.01-12.137$ (1942) (year items become income); 5 id. $\$ \$ 27.52-27.63$ (Rev. 1953) (year to deduct taxes); id. $\$ \$ 28.47-28.4 \$$ (year to dedust losses); id. $\$ \$ 30.19-30.22$ (year to deduct bad debts). The problem hereafter diseussed affects income taxation as well as gift taxation. However, judicial construction of Section 3801 of the Code, relating solely to income taxation, seems to alleviate the difficulty in that field. For discussion of the statute and its interpretation, see note 67 isf fra.

2. INT. REv. Cone $\$ 1000$ (a). For detailed discussion of the method of computation, see U.S. Treas. Reg. 10\$, $\$ \$ 8.6-86.7$ (1943), as amended by T.D. 5698, 1949-1 Cu2s. BuLl 226, 229.

3. A person who makes any transfer by gift must file a gift tax return, listing all gifts made during the calendar year. INT. Rev. CODE $\S 1005$; U.S. Treas. Reg. 108, $\$ \$ 6.20$ (1943), as amended by T.D. 5698, 1949-1 Cusr. Boul. 226, 239. The Commissioner determines that the return is incomplete if he concludes that a giit, not reported in the return, was actually made during that year. He then determines a deficiency in the return. INr. REv. CoDE $\$ 1012$; U.S. Treas. Reg. $10 \$$, $\S \& 6.39$ (1943), as amended by T.D. 5503, 1946-1 Cuxr. BuLL. 156, 158.

4. Compare Harris v. Commissioner, 178 F.2d $\$ 61$, 865 (2d Cir., 1949), rcoid on other grounds, 340 U.S. 106 (1950) ; Estate of Copley v. Commissioner, 194 F.21 364 (7th Cir. 1952), with Commissioner v. Allen, 108 F.2d 961, 963 (3d Cir. 1939), ccrl. denied, 309 U.S. 680 (1939), 53 HARv. L. Rev. 690 (19\%0); City Bank Farmers Trust Co. v. Hoey, 101 F.2d 9 (2d Cir. 1939). For general discussion of what constitutes a taxable gift, see 2 Paur, Estate aNd Gift Taxition 1059 el seq. (1942).

5. Estate of Sanford v. Commissioner, 308 U.S. 39, 45 (1939); Burnet v. Guggenheim, $28 S$ U.S. 280 (1933); cf. Smith v. Shaughnessy, 318 U.S. 176, 181 (1943); Robinette v. Helvering, 318 U.S. 1S4, $18 \$$ (1943). For discussion of the gift tax effect of 
the tax; statutes limiting the period in which an action can be brought or appealed may then preclude assessment in the correct year. ${ }^{\circ}$

To play safe, the Commissioner often presents the possible tax years alternatively and lets the court choose between them. ${ }^{7}$ But the trial court may also select the wrong year for taxation. After the court of appeals reversal of the lower court's erroneous choice, the tax can be imposed only if it is computed in the correct year's assessment. Because the running of the time for appeal may preclude this, presenting alternative years may be ineffective.

In the recent case of Rosenthal $v$. Commissioner, ${ }^{8}$ a shrewd taxpayer apparently evaded a gift tax, even though the Commissioner proposed alternative years. In $1944,{ }^{9}$ taxpayer entered into a marital separation agreement whereby he promised to make annual support payments to his children. ${ }^{10}$ In 1946

retaining powers over a gift, see 2 Paul, Estate and Gift Taxation 1126 ct sc $q$. (1942) ; Magill, The Federal Gift Tax, 40 CoL. L. Rev. 773, 778 ct si'q. (1940).

The Commissioner faces the same problem when the donor grants powers to be exercised by a third person, in conjunction with the donor. If the third party does not have a substantial adverse interest, the donor himself will be considered as retaining the powers. U.S. Treas. Reg. 108, $\$ 86.3$ (1943), as amended by T.D. 5366, 1944 Cum. BuLL. 583, 584, T.D. 5606, 1948-1 Cunr. Bull. 129, 130, and T.D. 5833, 1951-1 CuM. But. 83, 85. See also 2 PaUl, Estate and Gift Taxation $\$ \S 17.09-17.11$ (1942).

6. INT. Rev. CoDE $\$ 1016$ (limit of three years from date of return for making deficiency assessment); $i d . \S 1142$ (three-month limit on appeal of Tax Court decisions) 28 U.S.C. § 2107 (1946), as amended, 63 STAT. 104 (1949), 28 U.S.C. \& 2107 (Supp. 1952) (sixty-day limit on appeal of district court decisions to courts of appeals); 28 U.S.C. \$2101 (c) (1946), as amended, 63 StAT. 104 (1949), 28 U.S.C. §2101 (Supp. 1952) (ninety-day limit on application to Supreme Court for writ of certiorari).

7. To present the alternative years to the Tax Court, the Commissioner would assess a deficiency in both years for the transaction in question. The taxpayer, objecting to double taxation, would undoubtedly appeal to the Tax Court. Thus, the Tax Court would have jurisdiction over both years; and the deficiency for the incorrect ycar would be expunged. INT. REv. CoDE \& 1012(a) (1).

This procedure would not be necessary where the taxpayer's gift tax liability for one of the alternative years is already before the Tax Court. In such event, The Commissioner need only assess a deficiency for the transaction in the other alternative year, and then join the two years in one action. The Tax Court can sustain the new deficiency. Or it can increase the deficiency for the year which was already before the court, if it finds that year to be the correct one. INT. REv. CaDE $\$ 1012(\mathrm{c})$. And the deficiency in the other year can then be eliminated. INT. REv. CoDE $\$ 1012$ (a) (1).

8. 205 F.2d 505 (2d Cir. 1953). The Commissioner has decided not to petition the Supreme Court for certiorari. 4A P-H FED. TAX SERv. \ 132,103 (1953).

9. The agreement was entered into on July 26, 1944. The agreement provided that in the event of divorce, it was to become part of the divorce decree; but its effectiveness did not await the granting of a divorce. On September 18,1944, a divorce was obtained. This agreement was expressly adopted by the court and included in the decree. Rosenthal v. Commissioner, 205 F.2d 505, 506 (2d Cir. 1953).

10. The agreement provided for payments to both wife and children. $A$ major portion of the gift to the children $(\$ 150,000$ trust fund and $\$ 3000$ annually to each child) was contingent upon the death of taxpayer's mother during his lifetime. Patul 
the agreement was revised. ${ }^{11}$ In the Tax Court, ${ }^{12}$ the petitioner claimed that the agreement was not taxable as a gift. ${ }^{13}$ The Commissioner argued that a gift tax should be paid, either in the 1946 or 1944 assessment. 14 The Tax Court held the agreement taxable in 1946. The court never discussed the possibility of taxing it in $1944,{ }^{15}$ although the same proceeding adjudicated the petitioner's tax liability for other 194.4 gifts. ${ }^{10}$ Because the Commissioner approved of the Tax Court's decision, he did not appeal it." The taxpayer filed no appeal until the very end of the three month period in which review of a Tax Court decision must be sought. ${ }^{18}$ He worded his petition so that it

Rosenthal, 17 T.C. 1047,1052 (1951). Dispute as to year of taxation involvad only the gift to the children. No objection was made by either party to the Tax Court's determination with regard to the gift to the wife. Rosenthal v. Commissioner, 205 F.2d 505 , 507 (2d Cir. 1953).

11. The revised agreement translated all taxpayer's obligations to the children under the 1944 agreement into two trust funds of $\$ 312,000$ each, plus an annual payment of $\$ 3,000$ to each daughter until the wife's death, and of $\$ 1, \$ 00$ thereafter. The contingent obligation in the first agreement had become due, since taxpayer's mother had died in the interim; the revision replaced this as well. This 1946 agreement was to be effective only upon its inclusion in the divorce decree. Such amendment was made on March 29, 1946. Paul Rosenthal, 17 T.C. 1047, 1055, 1056 (1951).

12. For purposes of this Note, both the Tax Court and its predecescor, the Board of Tax Appeals, will be referred to as the Tax Court. See Irrt. Rer. Cors $\$ 1160$.

13. Brief for Petitioner, pp. 35-41, Paul Rosenthal, 17 T.C. 1047 (1951). Taspayer based this claim on the ground that the 1946 agrcement was made for an adcquate and full consideration, the surrender of the children's rights under the 1944 agreement. See U.S. Treas. Reg. 10\$, $\$ \$ 6.8$ (1943) (transfer of property in ordinary course of business will be considered as made for full consideration); Harris v. Commissioner, 340 U.S. 105, 112 (1950) (family transaction, where no donative intent, may be considered made in ordinary course of business for gift tax purposes).

Taxpayer further argued that no part of the 1946 agreement was taxable as a gift since it was effective only upon the entry of the amended divoree decree. Brief for Petitioner, pp. 40-1, Paul Rosenthal, 17 T.C. 1047 (1951). See Harris v. Commissioner, supra; Commissioner v. Converse, 163 F.2d 131 (2d Cir. 1947) ; Pedrick, The Gift Ta.r Jurisdiction of the Diz'orce Coutrt, 46 ILL L. Kev. 177 (1951).

14. Brief for Respondent, p. 59 (typewritten), Paul Rosenthal, 17 T.C. 1047 (1951); Paul Rosenthal, supra, at 1063 . The Commissioner believed that since the gift to the children was contingent upon the death of taspayer's mother, it should be taxed in 1946. Brief for Respondent, supra, at 51-4. In the alternative, however, the Commissioner argued that if the Court could value the gift while contingent, it should be taxed in 1944 . Id. at 59. For discussion of the tax treatment of contingent gifts, see text at note 4, suspro.

15. Having taxed the gift in 1946, the Court found it "unnecessary to examine such alternative contention." Paul Rosenthal, 17 T.C. 1047, 1063 (1951).

16. Id. at 1057-60. The 1944 deficiency was due to the taxpayer's gift to his wife. See note 10 supra. If the Tax Court had not already had jurisdiction over the taxpayer's liability for 1944, the Commissioner could still have presented alternative years for taxing the gift to the children. See note 7 supra.

17. Rosenthal v. Commissioner, 205 F.2d 505, 511 (2d Cir. 1953). The Commissioner acquiesced to the Tax Court decision. 1952-1 Cuss. Buls. 4.

18. Rosenthal v. Commissioner, 205 F.2d 505, 511 (2d Cir. 1953). See Int. Rer. CoDe $\$ 1142$ (three-month time limit for appealing Tax Court decisions). 
was limited to that portion of the decision which dealt with the 1946 assessment. ${ }^{19}$ The Second Circuit reversed, holding that the gift should have been taxed in 1944 rather than 1946. ${ }^{20}$ But the Court also concluded that the 1944 deficiency could not be redetermined. ${ }^{21}$ On the ground that two separate tax years were involved, the Court held that the 1946 and 1944 deficiencies constituted separate decisions. ${ }^{22}$ Since neither party had appealed the 1944 decision within three months, ${ }^{23}$ it had become final. ${ }^{24}$

This decision is clearly inequitable; even the opinion labels it "unfortunate." ${ }^{25}$ The Commissioner suggested 1944 as one alternative year for assessment. ${ }^{26}$ Yet, because the Tax Court erred, ${ }^{27}$ the petitioner evaded the tax

19. Brief for Petitioner, p. 1, Rosenthal v. Commissioner, 205 F.2d 505 (2d Cir. 1953) ; Rosenthal v. Commissioner, supra, at 511.

The Commissioner, however, alleged that the effect of taxpayer's appeal was to prosent both the 1944 and 1946 deficiencies for review. Brief for Appellee, p. 1, Rosenthal v. Commissioner, stipra.

20. Rosenthal v. Commissioner, 205 F.2d 505, 509 (2d Cir. 1953).

21. Id. at 511-12. See note 24 infra.

22. Rosenthal v. Commissioner, 205 F.2d 505, 512 (2d Cir. 1953). For discussion of the separate tax year doctrine, see pp. 247-9 infra.

23. See note 18 supra. The Tax Court decision was entered on March 4, 1952. Appendix to Brief for Petitioner, p. 35, Rosenthal v. Commissioner, 205 F.2d 505 (2d Cir. 1953). The Second Circuit did not decide the appeal until June 24, 1953. Rosenthal v. Commissioner, 205 F.2d 505 (2d Cir. 1953).

24. INT. REv. CODE $\S 1140$ (a) (Tax Court decision becomes final if no petition for review filed within the appeal period).

The Second Circuit specifically found itself barred from increasing the 1944 deficiency to include the gift to the children, while the case was before it. Further, the court stated that the Tax Court, on remand, was likewise precluded. It did, however, leave the Tax Court free to tax that gift, if the Commissioner shed "new light" on the problem. Rosenthal v. Commissioner, 205 F.2d 505, 512 (2d Cir. 1953). Any Tax Court redetermination of the 1944 deficiency would require a finding that the 1944 deficiency had not become final pursuant to Section 1140 of the Code. But this is directly contrary to the Second Circuit holding that the two tax years were separate decisions. Rosenthal v. Commissioner, 205 F.2d 505, 512 (2d Cir. 1953). By the doctrine of the law of the case, increasing the 1944 deficiency would thus seem impossible. Insurance Group Committee v. Denver \& Rio Grande Western R.R., 329 U.S. 607, 612 (1947) (matters decided by appellate court bind a lower court on remand); Stock Yards National Bank of South St. Paul v. Commissioner, 169 F.2d 39 (8th Cir. 1948) (stume in tax litigation). For discussion of the law of the case doctrine, see Moore \& Oglebay, The Supreme Court, Stare Decisis and Law of the Case, 21 Texas L. Rev. 514, 540 et seq. (1943).

The Commissioner will argue, however, that the Tax Court can consider both ycars and thereby increase the 1944 deficiency. Communication to the YALE LAW JounNAL from Harold D. Thomas, Acting Appellate Counsel to the Commissioner, dated October 7, 1953, in Yale Law Library.

25. Rosenthal v. Commissioner, 205 F.2d 505, 511 (2d Cir. 1953).

26. Brief for Respondent, p. 59 (typewritten), Paul Rosenthal, 17 T.C. 1047 (1951); Paul Rosenthal, supra, at 1063.

27. As the Second Circuit held, the Tax Court should have taxed the gift to the children in 1944, instead of 1946. Rosenthal v. Commissioner, 205 F.2d 505, 509 (2d Cir. 1953). 
entirely. ${ }^{28}$ Moreover, the decision's effect transcends the one controversy. To prevent repetition of such tax evasion, the Commissioner must initiate an appeal from every decision in which he presented alternative years-even though his determination of taxability was upheld. ${ }^{29}$ This seems like a wasteful and unnecessary burden. ${ }^{30}$

The Second Circuit's conclusion is far from necessary. The Court premises its reasoning on the applicability of the separate tax year doctrine. ${ }^{31}$ To ensure a tax which is ascertainable and payable at regular intervals, ${ }^{32}$ the doctrine prevents both taxpayer and Commissioner from recognizing a gift

Credit must also go to the taxpayer who did not file his petition for review until the last day of the statutory period for appealing Tax Court decisions. Id. at 511. Had the petition been filed earlier, the Commissioner would have had sufficient time to crossappeal, if he so desired. However, it is doubtful that he would have done so. The Commissioner contended that the taxpayer's appeal of one of the years presented both for review. Brief for Appellee, p. 1, Rosenthal v. Commissioner, 205 F.2d 505 (2d Cir. 1953).

28. See note 24 stipra.

29. This would seem the consequence of the Second Circuit's holding that the Commissioner's failure to cross-appeal prevented increasing the 1944 deficiency. Rosenthal v. Commissioner, 205 F.2d 505, 511 (2d Cir. 1953). The Commissioner has not yet decided what action he will take in similar cases. Communication to the YALE LAW Jormsin. from Harold D. Thomas, Acting Appellate Counsel to the Commissioner, dated October 7, 1953, in Yale Law Library.

30. Instead of the courts' requiring an appeal, it would seem logical for them to assume that where alternative years are presented, an appeal of one year gives the appellate court jurisdiction over the alternative as well. Certainly the rarty who presented alternatives in the trial court would desire to present the alternatives again on appeal. Furthermore, a miasma of confusion will result from requiring an appeal. Even if the taxpayer does not appeal at first, the Commissioner must still file his petition for review. The taxpayer may wait until the last day to appeal; and it may then be too late for the Commissioner to do likewise. Moreover, this decision may also compel taxpayers to appeal every case in which the Commissioner presented alternative years. The Commissioner might appeal the alternative year in which the transaction had not been tased. If the court of appeals then holds that the wrong year was chosen by the Tax Court, the one transaction may be taxed in both years. E.g., Lembcke v. Commissiuner, 126 F.2d 940 (2d Cir. 1942) ; Bigelow v. Bowers, 68 F.2d 839 (2d Cir. 1934), ccrt. denicd, 292 U.S. 656 (1934). But cf. Bull v. United States, 295 U.S. 247, 260-1 (1935). The only avowcd purpose of such cross-appeals is to delay the finality of the decisiun as to one year until the alternative year becomes final. The party so appealing may be penslizsd. Damages can be imposed for frivolous and delaying appeals. Irr. REv. Cons $\$ 1141$ (c) (4); 62 Stat. 954 (1948), 28 U.S.C. $\$ 1912$ (Supp. 1952). See Slalser v. O'Conner, 278 U.S. 183 (1928); In re Midland United Company, 141 F.2d 692 (3d Cir. 1944).

31. Rosenthal v. Commissioner, 205 F.2d 505, 512 (2d Cir. 1953): "[Transferring the 1946 deficiency to 1944] seems precluded . . . by the operation of the settled rule that each taxable year is to be treated as a separate unit for assessment and decisional purposes...."

This doctrine has been used mainly in income tax litigation. See note 34 infro. But since both the income tax and gift tax are computed on an annual total, it is applicable to gift taxation as well. Compare INT. Rev. Cone $\$ 11$ (income tax), wrilh I:ir. REv. Cons $\$ 1000$ (gift tax).

32. Sce Burnet v. Sanford \& Brooks Co., 282 U.S. 359, 365 (1931). 
in a year other than the one in which it is made ${ }^{\mathbf{3 3}}$ and it prevents revision of a prior year's tax because of events in subsequent years. ${ }^{34}$ But no stich attempt is made in Rosenthal and cases like it. The Commissioner proposed alternative years not to tax the gift in an improper year, but only to allow the court to determine the correct one. And there could be no revision of an earlier tax because of subsequent events; only one transaction occurreclthe taxpayer's gift to his children. ${ }^{35}$ Yet the court held that where one case involving one transaction is linked to two tax years, ${ }^{30}$ the separate tax yenr doctrine splits the case into two decisions, each requiring a separate appeal. ${ }^{\text {ar }}$ Contrary to precedent, ${ }^{38}$ the Second Circuit thus warped an accounting rule,

33. Security Flour Mills Co. v. Commissioner, 321 U.S. 281, 286 (1944). See also Burnet v. Sanford \& Brooks Co., 282 U.S. 359, 363 (1931): "All the revenue acts which have been enacted ... have uniformly assessed the tax on the basis of annual returns showing the net result of all the taxpayer's transactions during a fixed accounting period. ..." (emphasis added).

34. E.g., where an employee is compelled to return part of a bonus received in a prior year, it must be reported as an income loss in the year returned; the tax of the year in which the bonus was first reported as income cannot be revised. United States v. Lewis, 340 U.S. 590 (1951). A profit in one year must be reported as income in that year's rcturn, even though the taxpayer incurred a loss in the same transaction in other years. Burnet v. Sanford \& Brooks Co., 282 U.S. 359 (1931). All income must be reported in the year of receipt ; if continuing litigation requires a refund of part of the income, a loss would be deducted in the year the litigation is concluded. North American Oil Co. v. Burnet, 286 U.S. 417, 424 (1932). Accord, Lockard v. Commissioner, 166 F.2d 409, 414 (1st Cir. 1949) (subsequent events do not affect value of gift when made).

35. The Commissioner presented alternative years only as to the gift to the children. Paul Rosenthal, 17 T.C. 1047, 1063 (1951). The gift to the wife was outright; it was agreed that it was taxable, if at all, only in 1944. But the gift to the children was contingent. See note 10 supra. If it was too contingent to be valued in 1944, the Commissioner suggested taxing it in 1946; otherwise, he proposed 1944. Brief for Appellee, pp. 25-6, Rosenthal v. Commissioner, 205 F.2d 505 (2d Cir. 1953). Thus, there was no attempt to revise an earlier tax because of a subsequent year's events.

36. The single decision of the Tax Court entered March 4, 1952 read:

"ORDERED AND DECIDED: That there are deficiencies in gift tax for the years

1944 and 1946 in the respective amounts of $\$ 23,194.37$ and 16,983.17."

Quoted in Appendix to Brief for Petitioner, p. 35, Rosenthal v. Commissioner, 205 F.2d 505 (2d Cir. 1953).

37. See notes 21,24 supra.

The opinion itself is confusing in its holding that the two tax years were soparate decisions. The Tax Court finding is first referred to as a "decision," in the singular. Rosenthal v. Commissioner, 205 F.2d 505, 511 (2d Cir. 1953). Further on in the opinion, the Second Circuit states that a conceivable argument could be made to combine the two deficiencies to make one judgment, thus implying a prior holding of two decisions. Id. at 512 . Immediately following, the single decision argument is held to be untenable, since the separate tax year doctrine requires treating each tax year as a separate decision. Ibid. It would thus seem that the court meant to treat the two years as separate decisions throughout.

38. The court cites two cases as precedent for its application of the scparate tax year doctrine: Arrowsmith v. Commissioner, 344 U.S. 6 (1952), and Morris K. Wilson, 42 
designed for administrative convenience, ${ }^{39}$ into a technicality of legal procedure.

Since the separate tax year doctrine was not applicable, the Tax Court's determination in Rosenthal was a single decision. And because the taxpyyer appealed, that decision was not final. In remanding, should have held that the Tax Court, then revested with jurisdiction over the entire case, could have taxed the gift in the correct year."1

The Court had precedent for such a holding. In Champlin v. Commissioner, ${ }^{42}$ a closely analogous case, the Tax Court chose the incorrect one of two alternatives posed by the Commissioner. ${ }^{43}$ The taxpayer appealed and

B.T.A. 1254 (1940). In Arrou'smith, the court stated that the doctrine was applicable to prevent a revision of a prior year's tax, due to events in a subsequent year. The actual question involved here, that of treating two tax years as separate decisions, was not discussed. In Wilson, two tax years, included in one Tax Court decision, were held separate for assessment purposes. The Court based this holding on the reasoning that the tax year not appealed was both itnrelated to the other tax year, and undisputed. The Commissioner did not present these years as alternatives for taxing any transaction. Rather, they were joined in one action due to a time coincidence. Further, neither party disputed the deficiency of the year not appealed. On these grounds, the Court held that, when all dispute involving a taxpayer's liability for one year is settled, the Commissioner must notify the taxpayer of the assessment within the time required by statute. The Commissioner had failed to do this in Wilson. The Tax Court admitted it had no authority for even this narrow holding.

Furthermore, there is precedent that two tax years are not necessarily two separate decisions. In one such case, a single deficiency letter sent to the taxpayer included all years from 1917 to 1922 . The taxpayer appealed only 1917 through 1920 to the Tax Court. But the Tax Court decision embraced all the years in the deficiency letter. On taxpayer's objection to the decision's covering all six years, the D.C. Circuit held that the appeal of any of the years in one deficiency letter carried with it the appeal of all years in the same letter. Pabst v. Lucas, 36 F.2d 614 (D.C. Cir. 1929), cert. denied, 281 U.S. 741 (1930). Another such case is Commissioner v. Ray, 88 F.2d 891 (7th Cir.), cert. devicd, 301 U.S. 711 (1937). There, the Seventh Circuit held that where two years are litigated jointly, a request to transfer the taxation of one transaction from one year to the other does not represent a new claim. The Court stressed that since it is the taxation of the same transaction, it is the same claim. Cf. Jacob Brothers Co. v. Commissioner, 64 F.2d 107 (2d Cir. 1933) semble. But cf. Bush v. Commissioner, 175 F.2d 391 (2d Cir. 1949) (each tax year is a separate cause of action for deciding whether res judicata).

39. See text at note 32 sipra.

40. Appellate courts have previously used the reversal and remand technique to protect litigants whose reliance on the lower court's misconstruction persuaded them to forego appeal during the period prescribed by statute. Rorick v. Everglades Drainage District, 307 U.S. 208 (1939) ; Oklahoma Gas \& Electric Co. v. Ollahoma Pacling Co., 292 U.S. 386 (1934) ; John Simmons Co. v. Grier Brothers Co., 258 U.S. 82 (1922) ; In re Barnett, 124 F.2d 1005, 1011 (2d Cir. 1942) (alternative holding).

41. See Kaplan v. Joseph, 125 F.2d 602, 606 (7th Cir. 1942): "After reversal [of the] decree... [t] he parties were in precisely the same situation as though no decree had been entered."

42. 78 F.2d 905 (10th Cir. 1935).

43. H. H. Champlin, 2S B.T.A. 264 (1933).

The taxpayer held an oil lease, the title to which was then contested in litigation. He 
procured a reversal,44 but on remand the Tax Court sustained the Commissioner's alternative position. ${ }^{45}$ Again the taxpayer appealed, arguing that since the Commissioner had filed no cross-appeal from the Tax Court's first decision, that court, on remand, did not have jurisdiction over the other alternative. ${ }^{46}$ Like Rosenthal, however, Champlin turned on a single issue. ${ }^{47}$ Hence the Tenth Circuit held that the Commissioner's failure to take a crossappeal did not preclude inquiry into the alternative argument on remand 48 indeed, the Commissioner had no reason to appeal the first decision, since he had prevailed. ${ }^{49}$

The Rosenthal opinion states ${ }^{50}$ that Helvering v. Pfeiffer ${ }^{51}$ in effect overruled Champlin. This seems incorrect. To be sure, Pfeiffer held that failure to appeal one part of a decision renders final that part of the Tax Court's determination. ${ }^{52}$ But there the Commissioner did not present alternative arguments. Rather, he claimed categorically that two separate transactions were both taxable. Only on the taxpayer's appeal did the Commissioner interpose an alternative method of taxing one of the two transactions; he had not

formed a corporation and transferred the lease to it, in return for all of the corporate stock. A tax was assessed on the gain resulting from that exchange. The Commissioner presented alternative arguments concerning the method of valuing the lease and stock. He first argued that the title hazard required only a 25 percent reduction in the fair market value of the stock, and that no such reduction was required in arriving at the fair market value of the leased property for the purpose of computing the taxpayer's depletion allowance. Alternatively, the Commissioner contended that if his valuation of the stock was further lowered due to the title hazard, then a corresponding reduction should be allowed in his valuation of the property for depletion purposes. Id. at 264-8.

44. Champlin v. Commissioner, 71 F.2d 23 (10th Cir. 1934).

45. H. H. Champlin, 31 B.T.A. 587 (1934).

46. Champlin v. Commissioner, 78 F.2d 905, 907 (10th Cir. 1935).

47. The only pertinent issue involved in Champlin was the effect of title litigation on the value of the lease holding for tax purposes. The Commissioner suggested alternative methods of valuation. See note 43 supra. One of the Commissioner's alternatives would increase the capital gains tax; the other would result in an increased income tax. Similarly, the only issue involved in Rosenthal was the year in which to tax the gift to the children. The Commissioner presented alternative years. See note 14 supra. One of the Commissioner's alternatives would increase taxpayer's 1946 liability; the other would increase his 1944 liability.

48. The Court expressly stated that "[e]ven if so requested by the Commissioner, we could not and would not have tried the alternative issue not decided by the Board.... If this Court had noticed it in the first opinion, it would have been only to remand that issue to the Board for redetermination." Champlin v. Commissioner, 78 F.2d 905, 907 (10th Cir. 1935).

49. Champlin v. Commissioner, 78 F.2d 905, 907 (10th Cir. 1935) : ". . the Commissioner prevailed before the Board on the first hearing. There was nothing from which he could appeal nor to which error could be assigned."

50. Rosenthal v. Commissioner, 205 F.2d 505, 511 (2d Cir. 1953).

51. 302 U.S. 247 (1937).

52. Helvering v. Pfeiffer, 302 U.S. 247, 250 (1937). 
presented it to the Tax Court. ${ }^{53}$ Champlin and Roscuthal both involved the tax treatment of only one item. And both alternatives for treating it were argued before the Tax Court. ${ }^{54}$ Thus Pfciffor is distinguishable from both the Champlin and Rosenthal situations. Hence the Second Circuit, in Roseinthal, should have relied on Champlin and permitted the Tax Court on remand to increase the 1944 deficiency. ${ }^{55}$

The Court of Appeals could have used another rationale to tax the gift in question. Unless he files a cross-appeal, an appellee cannot request that the amount of the judgment below be increased.50 But barring an increase, an appellate court can utilize any part of the record to affirm the decision below $5 i$ -even where the trial court's grounds were improper."ss Considering the Tax Court's decision a single one, ${ }^{59}$ the Rosenthal court could have affirmed, remanding the case for a computation of the value of the gift in $1944 .{ }^{.00}$ This amount, added to the taxpayer's other 1944 tax liability, ${ }^{01}$ would then con-

53. In Pfeiffer, the taxpayer received a stock dividend in 1931. During the same year, he redeemed, in cash, a 1928 stock dividend. The Commissiuner assesscd a deficiency, claiming that both the stock dividend and the cash redemption were taxable as income. He disallowed the taxpayer's treatment of the cash redemption as a capital gain. In its decision, the Tax Court held the stock dividend taxable, but not the cash redernption. On taxpayer's appeal to the Second Circuit, the decision was reversed. The court held that the stock dividend was exempt from taxation; the cash redemption should have teen taxed. But it refused to consider taxation of the cash redemption. It could not be taxed as a capital gain since the Commissioner had never raised this possibility before the Tax Court. The redemption also could not be taxed on the grounds first offered by the Commissioner since such grounds required a finding of fact by the trial court that never was made. Pfeiffer v. Commissioner, SS F.2d 3 (2d Cir. 1937), aff'd, 302 U.S. 247 (1937).

54. See notes 43,14 supra.

55. Instead, the Second Circuit stated that the 1944 deficiency seemed final. Rosenthal v. Commissioner, 205 F.2d 505, 511 (2d Cir. 1953).

56. Penfield Company of Calif. v. S.E.C., 330 U.S. 585 (1947) ; Morley Construction Co. v. Maryland Casualty Co., 300 U.S. 185 (1937); Southwestern Hotel Co. v. United States, 115 F.2d 686 (5th Cir. 1940), cert. denied, 312 U.S. 703 (1941); Cleveland Clinie Foundation v. Humphrys, 97 F.2d 849 (6th Cir. 1938), cert. devied, 305 U.S. 628 (1938).

57. United States v. American Railway Express Co., 265 U.S. 425, 435 (1924) ; Moore v. C. R. Anthony Co., 198 F.2d 607 (10th Cir. 1952); Shepard v. Commissioner, 101 F.2d 595 (7th Cir. 1939), cert. denied, 307 U.S. 639 (1939). Also see cases cited note 58 infro.

58. Brown v. Allen, 344 U.S. 443, 459 (1953); Helvering v. Gowran, 302 U.S. 233 (1937) ; Helvering v. Rankin, 295 U.S. 123 (1935) ; Hughes v. Commissioner, 38 F.2d 755 (10th Cir. 1930) (correct amount of deficiency is controlling, not the method of arriving at it).

59. The Second Circuit should have so considered it. See discussion of separate tar year doctrine, pp. 247-9 supra.

60. The gift to the children, if taxed in 1944, may have resulted in a larger tax than if taxed in 1946. The face value of the 1946 obligation was less than the face value of the 1944 obligation. Brief for Petitioner, p. 15, Rosenthal v. Commissioner, 205 F.2d 505 (2d Cir. 1953). On the other hand, since the 1944 obligation was only contingent, its value for tax purposes might have been less.

61. See note 16 supra. 
stitute the final judgment. ${ }^{62}$ But the total could not exceed the sum originally set by the Tax Court. ${ }^{63}$ Therefore, whenever it appears that the Tax Court's figure may fall short of the taxpayer's full liability, the technique of reversal and remand should be employed to ensure collection of the entire tax. ${ }^{04}$

The Rosenthal decision can be justified neither doctrinally ${ }^{05}$ nor pragmatically. ${ }^{60}$ By misapplying the separate tax year doctrine and misconstruing the Pfeiffer case, the Second Circuit has sanctioned tax evasion on technical grounds. The decision should not remain uncorrected. ${ }^{67}$

62. Since the Second Circuit would already have held the gift to the children taxable in 1944, no question would remain for the Tax Court but the valuation of the gift. Unless there was objection to the Tax Court's determination of the gift's value, this would conclude the litigation. See Moore \& Oglebay, supra note 24; cases cited note 24 supra.

63. See cases cited note 56 supra.

64. In Rosenthal, the tax may have been larger in 1944. See note 60 supra. Reversing and remanding would ensure full collection. See note 41 supra.

65. See text at notes 31-55 supra.

66. See note 30 silpra.

67. This can be achieved during this case's continued litigation. The Tax Court can increase the 1944 deficiency while Rosenthal is before it on remand. The Commissioner intends so to argue. Communication to the YALE LAw Journal from Harold D. Thomas, Acting Appellate Counsel to the Commissioner, dated October 7, 1953, in Yale Law Library. Undoubtedly, the taxpayer would appeal such a decision since he claims that the 1944 deficiency is closed. Reply Brief for Petitioner, p. 10, Rosenthal v. Commissioner, 205 F.2d 505 (2d Cir. 1953). The Second Circuit would then be reconfronted with the problem.

However, the doctrine of the law of the case would seem to preclude any Tax Court departure from the Second Circuit's holding that the two years were separate decisions. See note 24 supra. If the Tax Court is thus bound, the Commissioner can appeal to the court of appeals. And since an appellate court, unaffected by the law of the case doctrine, may reverse its own prior decision, the Second Circuit could now hold otherwise. But such a complete turnabout cannot be expected. If the Second Circuit does not annul its own error, and absent Supreme Court intervention, correction must await similar litigation in another circuit.

For discussion of techniques previously employed by courts to prevent either double taxation or omission from taxation due to statutory time limitations, see Maguire \& Zimet, Hobson's Choice and Similar Practices in Federal Taxation, 48 HARv. L. REv. 1281 (1935).

If the courts do not eliminate this tax loophole, Congress can do it by amending section 1142 of the Code providing that a Tax Court decision may be appealed if petition for review is filed within three months, to provide that where alternative years are jointly presented for the taxation of one transaction, an appeal of one tax year will automatically include the other.

Congress adopted section 3801 of the Code to prevent similar evasion of income taxes. This section prevents statutes of limitations from barring either collection or refund of taxes, where the benefited party takes a position contrary to the position he held prior to the running of the statute. Thus, tax years have been reopened to correct an erroncous omission, even though the statutory time limitation had run. Greenwood Packing Plant v. Commissioner, 131 F.2d 787 (4th Cir. 1942); Albert W. Priest Trust, 6 T.C. 221 (1946). For discussion of section 3801 of the Code, see Maguire, Surrey \& Traynor, Scction S20 of the Revenue Act of 1938, 48 Yale L.J. 509 (1939). At present, section 3801 specifically mentions only income taxes. An amendment to include gift taxes would also alleviate the instant problem. 